\title{
Scriptwriting as a creative, collaborative learning process of problem finding and problem solving
}

\author{
Eva Novrup Redvall, Department of Media, \\ Cognition and Communication, University of Copenhagen
}

Developing an original idea into a finished feature film script is often a time-consuming and highly collective process. It is also a learning process. Writing a script is about constantly learning more about what one wants to tell and the best way to tell it. This knowledge can, for instance, come from research, conversations with creative collaborators, or improvisations with actors. In current Danish feature filmmaking this exploration of the material often takes place in close collaboration between the director and the scriptwriter (and sometimes also the producer) who together learn more about their initial idea for a film and about the best way to meet the challenge of writing the script.

This article analyzes the collaborative process in the idea development and scriptwriting phase between director Annette K. Olesen and scriptwriter Kim Fupz Aakeson based on a qualitative case study of their work in developing an initial idea into the feature film Lille soldat (Danish premiere November 14, 2008), viewing their work as a creative, collaborative learning process of continuous problem finding and problem solving.

Drawing on a study of problem finding in art by Mihaly Csikszentmihalyi and Jacob W. Getzels (1976) and theories from the field of Creative Problem Solving (CPS), the article explores the different stages and approaches of Olesen and Aakeson in their writing process and concludes how they go about learning more about their initial idea and why they embark on this problem finding and problem solving quest together. The case study shows how external parameters like institutional acceptance-finding and financing issues influence when to move from one stage in the scriptwriting process to another, and how a major reason for collaborating is having complementary skills that ensure on the one hand not being stuck in the mess-and data-finding stages of understanding an idea for too long, and on the other not moving on to a problem statement and generating ideas too quickly. 


\section{The creative vision and the process of art making}

Definitions of creativity focus on creativity as being the ability to produce work that is both novel (i.e., original, unexpected), high in quality, and appropriate (i.e., useful, meets task constraints) (Sternberg \& Lubart, 1999:3). The writing of a film is a setting for creative work, where practitioners try to develop a novel product of the best possible quality that meets the many constraints of the task, such as deadlines and budgets. Whether the final film is normatively regarded as being creative or of high quality is not of interest in this article. The focus is on the process and the methods used until a final draft of the script is regarded as having the artistic quality to move into production.

In The Creative Vision (1976), Csikszentmihalyi and Getzels conducted a longitudinal study of the creative work of painters and the process of problem finding in art. The first part of the study investigated students in the School of the Art Institute of Chicago to find out more about their backgrounds, mental and emotional characteristics, value systems, career thoughts, etc. The second part studied the making of art by conducting an experiment where students were observed from the time they began formulating a problem for a drawing all the way to the completion of it.

Csikszentmihalyi and Getzels' experiment was based on a model of problem finding as a cognitive process: "If the process of artistic creativity, and of creativity in general, is to be understood more fully, the study of what the artist does cannot be restricted to the visible solution, the finished product. It must include the earlier, crucial step: formulation of the creative problem to which the solution is the response. At the same time, we must bear in mind that the emergence of a problem in art is seldom a single event but rather a continuous, cumulative process of discovery which begins before the artist picks up a brush, and often does not end even after the canvas is hung on the walls of a museum." (Csikszentmihalyi \& Getzels, 1976, p. 5)

Csikszentmihalyi and Getzels based their case study on observation as well as qualitative interviews of the subject after the process, focusing on variables like "what is the work to be about (i.e., what is the problem); how is it to be done (i.e., what is the method); when is it completed (i.e., what is the solution)." (Ibid, p. 84) However, the central question became whether or not there is a significant relationship between the problem-finding behavior of fine art students and the aesthetic value, more specifically the originality, of the drawings they produce (Ibid).

As mentioned, this normative discussion of the quality of the finished work is not a part of my case study, which instead finds inspiration in the first three questions asked and combines them with a collaborative take on this process of problem finding in the scriptwriting of a feature film: How do a director and a scriptwriter collaborate in the different stages of finding and solving problems? And why do they choose this collaborative way of working?

A major reason for analyzing the process is to insist on the importance of a detailed account of a highly collaborative way of working that challenges the traditional, more compartmentalized view of the filmmaking process. While there is a widespread understanding that filmmaking involves a number of people collaborating, the process is often described as a multiplicative production process where specialized individuals take turns in contributing during separate stages of idea development, scriptwriting, script development, pre-production, production, post-production etc. (Caves, 2000). The writer first develops an original idea into a script. The director then moves into 
a pre-production phase of visualizing the words on the page, bringing the actors and the technical production crew in during production, which is consequently followed by the work of the postproduction crew to finish the film.

In contrast to the approach to studio filmmaking in the American script market, as described by Janet Wasko and others, where a vast amount of 'spec scripts' circulate waiting for a director to be attached (Taylor, 1999; Wasko, 2003), the reality of filmmaking in most current Danish films is a more collaborative approach, where ideas are developed into scripts in close collaboration between a director and a scriptwriter. This process has been discussed as partly originating from teaching at The National Danish Film School, where the importance of collaboration between the Scriptwriting Department and the student directors has been emphasized since the 1990's (Philipsen, 2005; Redvall, 2007a). Many directors and scriptwriters in Danish film develop scripts together all the way from an original idea to not only the final draft of the script, but also to the finished film with the writer also often being brought in during the 'rewriting' of the film in the final editing. Furthermore, this collaboration encourages elements of the development and pre-production phase to inform the writing process, asking for input from other members of the film team to contribute to the actual making of the script.

\section{The stages of the creative process}

A central point in Csikszentmihalyi and Getzels' study is to emphasize the idea of problem finding rather than only problem solving. ${ }^{2}$ They argue that "the main elements of creativity, as of other problem situations, are the formulation of a problem, the adoption of a method of solution, and the reaching of a solution" (Csikszentmihalyi \& Getzels, 1976, p. 79). However, while all problem situations share this structure, there is a difference in whether one is to discover a formulation, a method and a solution oneself or adopt existing structures.

Csikszentmihalyi and Getzels distinguish between the presented problem situations where the problem has a known formulation, a routine method of solution and a recognized solution, and the discovered problem situation where the problem does not yet have a known formulation, a routine method of solution or a recognized solution. In a discovered problem situation, the problem solver becomes the problem finder - "and when he reaches a solution - if he reaches it - he has no way of knowing whether it is right or wrong. Not only the solution, but also the problem itself must be discovered, and when the solution is found, it cannot be compared against predetermined standards. It can be accepted or rejected only on the basis of a critical, relativistic analysis - as in the case with works of art." (Ibid, p. 82)

Writing a script for a new feature film can be viewed as either a presented problem situation or a discovered one. Adapting a novel is in many ways a very specific problem to solve for a scriptwriter, while starting from scratch, as in the case of Lille soldat, is a long process of discovery and learning more about what the film is to be about. While analyzing this process of problem discovery when learning more about the idea for a film, this article draws on theories of the creative process from the field of Creative Problem Solving (CPS). The theoretical framework behind CPS 
was developed for teaching creativity. However, since the focus of this article is to understand and break down the creative process itself, it is also valuable to use CPS as a model for analysis of the creative processes.

\section{Creative Problem Solving}

The basic theoretical framework for CPS was initially formulated by advertising executive Alex Osborn in 1953 to describe an approach for consciously enhancing creativity in groups and indi-

\section{CPS version 4.0}

\section{UNDERSTANDING THE PROBLEM}

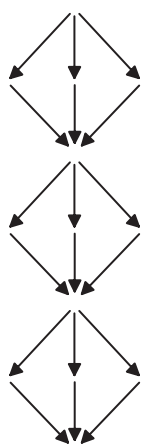

\section{Mess Finding}

Diverging: Seeking opportunities for problem solving

Converging: Establishing a broad, general goal for problem solving.

\section{Data Finding}

Diverging: Examining many details, looking at the mess from many viewpoints.

Converging: Determining the most important data to guide problem development.

\section{Problem Finding}

Diverging: Considering many possible problem statements.

Converging: Constructing or selecting a specific problem statement.

\section{GENERATING IDEAS}

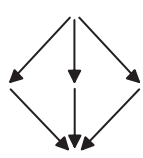

\section{Idea Finding}

Diverging: Producing many, varied, and unusual ideas.

Converging: Identifying promising possibilities, alternatives or options having interesting potentials.

\section{PLANNING FOR ACTION}

\section{Solution Finding}

Diverging: Developing criteria for analyzing and refining promising possibilities.

Converging: Choosing criteria, and applying them to select, strengthen, and support promising solutions.

\section{Acceptance Finding}

Diverging: Considering possible sources of assistance / resistance and possible actions for implementation.

Converging: Formulating a specific plan of action.

Figure 1. CPS Version 4.0. (Isaksen \& Treffinger, 2004, p. 14) 
viduals (Puccio et al., 2005, p. 53). ${ }^{3}$ As discussed by Isaksen and Treffinger (2004) and Puccio et al. (2005), CPS has since then been developed by a number of different researchers.

The model used in this article is the so-called 4.0 version of CPS by Isaksen and Treffinger (1992) that they have since reworked into new less linear versions with modifications of the different stages to emphasize the flexibility of the process (Isaksen \& Dorval, 1993; Isaksen et al., 1994; Isaksen et al., 2000). The 4.0 componential model builds on their earlier model from the basic course book for CPS from 1985 and draws on the three stages of fact-finding, idea-finding and solution-finding formulated by Osborn (1963). The 4.0 model describes the process as having three major components (understanding the problem, generating ideas and planning for action) and highlights how each step in the process is marked by first going through a diverging and then a converging phase.

An interesting aspect of Isaksen and Treffinger's model is their more explicit description of the 'front end' of the process. They insist that this beginning of the process is often a mess and that it is often more about finding data than pure facts. While the mess finding involves aspects like the personal orientation of the problem solver and the setting in which the work takes place, the data finding process recognizes the importance of feelings, impressions, observations and questions as well as facts since "the creative opportunity or challenge in a task pertains as much or more to what might be unknown, uncertain, or unclear than to the agreeable facts of the situation." (Isaksen \& Treffinger, 2004, p. 8) This inclusion of emotional issues and personal concerns makes this version of CPS more suitable for analyzing artistic processes of discovery than its more fact-oriented predecessors, which had a tendency to focus more on the 'back end' of the process with the solution rather than the problem finding.

Another quality of this model is its highlighting of the continuous dynamics between divergent and convergent, or creative and critical thinking. While it is possible to argue that the overall process moves from diverging stages of exploring many different possibilities and approaches, choices of problems and solutions have to be made at the converging back end of the model. However, Isaksen and Treffinger insist that each stage is characterized by a divergent and a convergent phase that they pinned down explicitly in their version of the model. They also insist that the process is flexible rather than linear and depending on the problem it might be a good idea to jump back and forth between the steps rather than using them in the order that they are stated in the model.

This article uses the model as a tool for discussing the different stages of the scriptwriting process of Lille soldat. As David W. Ecker discussed when writing about qualitative problem solving in the arts, qualitative problem solving is "not a neat progression of steps but a single, continuous mean-ends progression, sometimes hesitating, halting, groping; it may be rethought, move forward again, start over, in short, it is experimental behavior. And all that one can attempt is a logical analysis of distinguishable phases of the artistic process, as Dewey did in his description of scientific processes of thought. Rules, or recipes, as such, for producing good art (or science, for that matter) have never been established, and are perhaps anathema to the genuinely creative art of each age." (Ecker, 1963, p. 288)

The model of Isaksen and Treffinger provides a fruitful way of trying to organize an often chaotic scriptwriting process into stages where the work of understanding, finding and solving a problem becomes clearer although it does not necessarily move forward in a neat manner. Before moving on 
to the case study, aspects of creativity and collaboration will briefly be discussed, since this is not an analysis of an individual but a collaborative process.

\section{Creative work as a collaborative process}

Initially the field of creativity studies was oriented towards the creative process of the individual. However, over the years there has been a growing interest in studying creative groups, often with a focus on enhancing performance in organizational settings. Recent anthologies of independent studies like Group Creativity (Paulus \& Nijstad, 2003) and Collaborative Creativity (Miell and Littleton, 2004) or more popular publications like Group Genius (Sawyer, 2008) demonstrate the increasing interest in understanding the dynamics of creativity in groups in relation to concepts like idea development and innovation.

In her study of creative collaboration, Vera John-Steiner analyzes real intellectual and creative collaborations, arguing that "generative ideas emerge from joint thinking, from significant conversations, and from sustained, shared struggles to achieve new insights by partners in thought" (John-Steiner, 2000, p. 3). Relying on the cultural-historical ideas of L.S. Vygotsky, she stresses the importance of dynamic interdependence of social and individual processes that leads to "co-construction of knowledge, tools, and artifacts" (Ibid, p. 5).

Focusing on aspects like shared visions and shared growth, John-Steiner introduces four patterns of partnerships in what she terms 'thought communities'. "Thought communities are different from cooperating teams as their members take emotional and intellectual risks to construct mutuality and productive interdependence. Their objectives are to develop a shared vision as well as achieve jointly negotiated outcomes." (Ibid, p. 196). The four collaborative patterns consist of the distributed collaboration, the complementary collaboration, the family collaboration and the integrative collaboration.

Distributed collaboration is common and includes everyday conversations in professional gatherings like conferences, electronic discourse communities, or among artists who share a studio space. Similar interests link participants, but their roles are informal and voluntary (Ibid, p. 197-198). According to John-Steiner, complimentary collaboration is the most widely practiced form. It is "characterized by a division of labor based on complementary expertise, disciplinary knowledge, roles, and temperament. Participants negotiate their roles and strive for a common vision." (Ibid, p. 198).

The family collaboration is characterized by "a mode of interaction in which the roles are flexible or may change over time" as when "participants help each other to shift roles, including the move from novice to a more expert level" (Ibid, p. 201). In a family collaboration participants are normally committed to each other for a long time.

The aspect of long-term collaboration is central to the integrative collaborations that "require a prolonged period of committed activity. They thrive on dialogue, risk taking, and a shared vision. In some cases, the participants construct a common set of beliefs, or ideology, which sustains them in periods of adversity or insecurity. Integrative partnerships are motivated by the desire to transform existing knowledge, thought styles, or artistic approaches into new visions." (Ibid, p. 203). 
One of the central claims by John-Steiner's study is that these integrative collaborations are the best way for the construction of new modes of thought or new art forms, since it is hard to overcome the weight of disciplinary and artistic socialization alone. Analyzing why director Annette K. Olesen and scriptwriter Kim Fupz Aakeson collaborate and how this collaboration unfolds, I want to identify what pattern of collaboration it can be argued is central to their creative process.

\section{The case of Lille soldat}

The empirical material for this article consists of material gathered while following the scriptwriting process of Annette K. Olesen and Kim Fupz Aakeson from April 2007 until January 2008, when the shooting of the final script started. ${ }^{4}$

There were several reasons for choosing this specific case. Primarily, I wanted to investigate a process of a discovered problem situation where an original idea is being developed into a finished script. Being interested in analyzing an established collaboration, Olesen and Aakeson was an excellent case since Lille soldat is their fourth feature film together after Minor Mishaps (2002), In Your Hands (2004) and 1:1 (2006). ${ }^{5}$

In contrast to the artificial setting of Csikszentmihayli and Getzels' experiment, my case study is a real life case study. It is a unique single case study rather than a case of several practitioners where participants can be compared to produce quantitative data of how many painters had certain considerations when producing a painting. Discussing different approaches to studying creativity, Robert W. Weisberg stresses the strengths of case studies of high-level creativity in real time or "in vivo" investigations, using studies of ongoing activities in high-level research laboratories as an example (Weisberg, 2006, p. 84-85). An essential question when studying ongoing undertakings is of course whether one can be sure that creative work is produced. This case study argues that a feature film script is definitely a novel product. What can be discussed is the value or appropriateness of it. Somewhere along the line the script needs to find acceptance and be considered appropriate by gatekeepers in order to move into production, but whether the final film is considered of value by the audience or critics is then a whole different matter.

Based on Robert K. Yin's five rationales for single-case designs (Yin, 2003, p. 39-42), the case of Lille Soldat is both a unique and a revelatory case where the empirical material provides insight into a very little known field. Yin describes the revelatory case as justified when it "can uncover some prevalent phenomenon previously inaccessible to scientists" (Ibid, p. 42). One cannot really describe the scriptwriting process of a film as inaccessible per se, but the fact is that very few scholars have studied this process before. ${ }^{6}$

The intention with this case analysis is to shed light on the creative processes behind the writing of a film to provide material for greater understanding of the different stages and methods, as well as the nature of the creative collaborations. Therefore, there has been a strategic selection of the material focusing on the progression of the different stages in the process and the way choices are made to move forward, rather than the consequences of these choices on a textual level.

Writing about the history of film style, film historian David Bordwell argues for the value of 
viewing artistic continuity and change as a rhythm of problem and solution. According to him the problem/solution-model "invites us to reconstruct decisions made by active agents, and it treats persons as concrete forces for stability or change (or both)" (Bordwell, 1997, p. 150). However, at the same time the model recognizes "that individual action takes place within a social situation with its own demands. The artist's choices are informed and constrained by the rules and roles of artmaking." (Ibid, p. 151)

Studying scriptwriting as it unfolds provides a unique possibility of tracking the many different choices and what informs and constrains this process, rather than retrospectively trying to reconstruct this important stage of filmmaking.

\section{Understanding the problem; mess finding}

The case of Lille soldat began in the beginning of 2007 when scriptwriter Kim Fupz Aakeson suggested to Annette K. Olesen that they should make a gangster film together. Aakeson felt that the male directors in Danish film have monopolized the gangster genre and that it would be interesting if Olesen would take a shot at the genre in collaboration with him. Coming off 1:1, which had not been as well received as her two previous features, Olesen had been wondering what to do next and thought it would be 'fun' to work in a clear cut genre together with Aakeson for the first time.

Regarding the question of personal orientation and motivation, the use of the words 'fun' and 'exciting' keep reoccurring from both Olesen and Aakeson when describing what they personally search for when going into the process of making a film, as well as what they experienced in this specific context. They also use their intrinsic motivation as a sort of quality parameter by believing that what they find interesting in the process is what will interest the audience in the film (Olesen, 2008) and by letting an essential quality question to the text be 'Are we bored?' rather than "Will the audience be bored?' (Aakeson, 2008). 'Conversations about the potential audience of the film were not common during the early stages of the process, and both Olesen and Aakeson think that at this point the writing of the screenplay should be guided by their gut feeling, rather than taking the future film audience into consideration. Acceptance-finding was not a question specifically addressed in the early stages of the process, but started to become an issue from the point where the film consultant read and commented on the first draft.

Isaksen \& Treffinger has described the stage of mess-finding as the stage of "structuring your problem-solving efforts to identify and accept a challenge" (Isaksen \& Treffinger, 1985, p. 25). In Lille soldat a decision of genre was an initial guiding principle, but an agreement between Olesen, Aakeson and producer Ib Tardini was made about the overall aim of the process: "We agreed that we should learn something in the process of making the film," as Tardini has later explained (Tardini, 2008). Aakeson has summed it up: "We have to learn something. We have to get involved in public debate. We have to get involved in the Danish reality." (Aakeson, 2008) This agreement and the choice of genre became the guiding principle before starting searching for possible topics for a Danish gangster film in the data finding process. 


\section{Data-finding}

What first sparked Olesen and Aakeson's interest were a number of stories about trafficking in the press. This topic prompted discussions about cynicism; Discussions about how a different, secret world can be hidden in the middle of normal, everyday life. Originally, the idea was to tell a story about foreign women coming to Denmark to work as escort girls, portraying them as victims. However, according to Aakeson, the research made it clear that most foreign escort girls have an idea of what awaits them when they come to Denmark. It is a question of poverty and an attempt to get a better life. Many of the women are victims, but many of them are also independent women searching for an opportunity to improve their living conditions. Olesen and Aakeson therefore decided that it was not interesting to tell a story of a victim. It is sad being cheated and badly treated, but they found it hard to tell an interesting story about that. At the same time, they felt that a lesson learned from 1:1 was that a story often becomes sadder when it deals with a foreign environment in Denmark rather than focuses on the destiny of a Danish person.

During the research into the prostitution environment, Olesen started to become interested in a whole different topic; soldiers returning from Iraq and the fact that many of them don't know how to deal with their civilian life when coming home. This topic also had aspects of leading lives in the shadows, suitable for the genre, and they started doing parallel research into both topics.

This initial 'massaging' of the situation - to use a term coined by Isaksen and Treffinger - is the process of finding out what to actually make a film about. Decisions were made from the outset regarding the choice of genre, a desire to personally learn something, and a strategy of turning to reality as a source of inspiration for a potential story, guiding the research towards topics involving aspects of crime and conflict. The data finding process involved learning more about the topic of trafficking and prostitution in Denmark. Original hypothesis and clichés were challenged when the data showed that only a few foreign women are lured into coming to Denmark with no idea why, and when a number of conversations with both escort girls, social workers, and the police introduced a much more complex impression of the environments than what they had learned from reading the newspapers.

The previous collaborations between Olesen and Aakeson have all been based on extensive research. Olesen has described this research phase as absolutely essential to her work. Speaking of 1:1 she has described it as a search for the truth: "I wouldn't go into a story like One to One without being absolutely sure that what we are saying is, if not the actual truth, then at least a plausible version of it. I have to feel a certainty in my gut that we aren't just making up a story that more or less resembles newspaper headlines. Most press stories are incredibly simplistic and a big factor in creating the same divide that our film tries to bridge." (Michelsen and Piil, 2006)

Aakeson describes the research phase as essential in providing 'gifts' in terms of elements than one could never have made up sitting behind the desk, and by challenging the classic dramatic structures and routines that one has a tendency to automatically cling to. As an example, the first ending to be proposed for the first draft of the script was a classic dramatic ending, where Miriam saves the escort girl by sending her home with money in her hand. Technical advisors insisted that this ending would have to be much more complex, since most escort girls would never go home 
voluntarily. Thus, the project of Miriam became much more complicated than simply rounding the film off with her saving herself by saving somebody else. ${ }^{8}$

In the diverging process of data-finding many different environments were explored and many people confronted, before choices were made regarding the setting for a potential story with a focus on both trafficking and soldiers returning from Iraq.

\section{Problem-finding}

The original thought was to pick either the environment of trafficking or of soldiers returning from war, but when Olesen and Aakeson started formulating the first pitches for a potential story they decided to combine the two. In six of the seven first pitches from March and April 2007 the main character of their story is a son returning from Iraq, experiencing different storylines after having accepted work as a driver for one of his father's escort girls. The plots change from the disillusioned son taking over the position of his father to him saving himself by wanting to help one of the prostitutes to a better life.

In pitch 8 and 9 the soldiers name is suddenly Miriam. According to Aakeson the idea of making the soldier female came from Tardini who knew that Olesen was thinking about launching a different project with actors Jesper Christensen and Trine Dyrholm to have several possible films going at the same time. Tardini suggested changing the relationship of a father and a son to a father and a daughter with the two actors in the parts. This idea was debated a lot by Olesen and Aakeson. They decided to try it out for the first draft of the script, and an important reason for sticking with it was the reaction of film consultant Molly Malene Stensgaard from The Danish Film Institute. She read the draft and found that the aspect of the soldier being a woman was what really made this story novel and original in terms of the stories that had previously been told in Danish cinema. The concept of novelty and originality had otherwise not been discussed much by Olsen and Aakeson during the early stages. They had focused on the aspect of creating something new to them, rather than positioning their work as something new in regard to other Danish films. However, it could be observed how aspects of originality as a quality parameter were often addressed at meetings and during the work with the actors in the later stages of the process.

As mentioned, a central concept in the CPS model of Isaksen and Treffinger is that each step of the creative process consists of first going through a divergent phase where a lot of ideas and material is gathered without being analytical or critical, before then moving on to a convergent phase where judgment is allowed and choices are made to get to the essence of the problem. In the overall process, the first two stages of understanding a problem and generating ideas are characterised by a high degree of divergence to allow many dimensions to be explored before the solution and acceptance finding stages.

A key question is, of course, when this divergent phase ends and what makes it end; when to stop researching for potential stories and try to decide on a potential story. In the case of Lille soldat, a number of things forced choices to be made on paper before the summer, producing a first draft for the film consultant in May. A preliminary script was needed for financial reasons, both for the DFI and other financing sources. With Lille soldat logistical considerations also played a part, 
since Olesen wanted to shoot the film in the cold of winter, meaning that the script would have to be finished during the fall. Moreover, both Jesper Christensen and Trine Dyrholm are very busy actors, and would only be available if shooting started at the beginning of 2008.

When to start writing a first draft was an issue that was debated during the process, since Tardini was convinced that a problem with 1:1 had been that they had started writing too early and thereby constructed too much instead of keeping the material alive and more open to input. He believes that Olesen and Aakeson also started writing too early in the case of Lille soldat, but both Olesen and Aakeson insist firstly that they were asked to provide a draft for financing reasons and secondly, that for them, writing initial pitches and drafts is not closing a text. Tardini is afraid that they will cling to what is already on the paper, but they believe that writing is part of the process of finding the problem in all the material gathered. Olesen says her impression is that Tardini fears "that as soon as something is down on paper, then it very quickly becomes dogmatic. Then it becomes dogma, and what we are making. The real exercise is keeping it open as long as possible (...) So that one is continuously searching and it isn't suddenly what is on the paper that is guiding the search. "(Olesen, 2008) Olesen finds that one of Aakeson' virtues as a writer is his ability to keep the text open instead of allowing what is written down to become dogma. To her, this openness of the text is essential. (Olesen, 2008)

When studying the process of painters, Csikszentmihalyi and Getzels were keen to investigate the importance of what they termed "openness of the initial structure and content of the problem" (Csikszentmihalyi \& Getzels, 1976, p. 90). This dimension was studied by analyzing the length of time that the problem remained open for alteration based on an intention to know "when the essential form of the finished drawing could first be recognized" (Ibid, p. 91). The assumption was - much like Tardini's concern - "that closure of the problem must be delayed if a creative solution is to emerge; that a person who does not explore different methods of solution might transform a new idea into an old routine; and that changing elements and introducing new combinations - that is, going beyond the information given - is more likely to contribute to an original solution." (Ibid, p. 92).

\section{The first draft as a problem statement}

With regard to scriptwriting, a major issue is whether one regards the first draft as the first possible solution to a problem or rather the formulation of the problems to be solved in the extensive development and rewriting that follows. I would argue that a treatment or a first draft outlining a potential story with a beginning, a middle and an end is best considered as what Treffinger and Isaksen term the problem statement which ends the problem finding stage. The first draft puts down on paper the film the filmmakers are thinking of proceeding with, making the many concrete problems that need further investigation in the idea finding phase visible. In that sense, the first draft does two things: it specifies and clarifies several overall problems that need to be solved, and it concretizes very specific minor problems, like for instance how to get the relationship between father and daughter to work, how to create tension in the middle part of the story, or how best to end the story.

Many practitioners acknowledge looking at the first draft as a way of clarifying the problems in 
a screen idea. Jill Nelmes, writing about the process of developing the script Wingwalking, describes the first draft "as the 'puke draft' - a quickly written draft intended to get the idea down on paper rather than to be a working document" (Nelmes, 2008, p. 336) or "the exploratory draft, driven by the initial excitement and passion for the project while the story and the characters are still evolving" (Ibid, 343). A director like Per Fly finds the first draft with all its faults and visible problems too painful to write himself, making collaboration with a scriptwriter who can provide a first draft essential to his work process (Fly, 2008). However, the first draft also serves the purpose of making the idea for a film - with all its problems - more easily understandable for others; not only potential investors, but also other creative collaborators who are invited to play with ideas for solving the problems in the draft.

In a thesis on the development processes in Danish film, Sara Malou Strandvad identifies the externalization of an idea as the first key moment in enabling collaborations (Strandvad, 2008, p. 162). The externalization of the idea can be in different forms, but as Strandvad points out, "the externalized idea can be seen as representing a fixed agreement about the prospective product. In contrast to thoughts and talks, which are fluctuating, a draft stabilizes the idea (cf. Mukerji 1994; Latour and Woolgar 1979). By this, it stabilizes the alliance between the participants." (Ibid, p.164) Strandvad continues to stress that "rather than being a finished work made by an individual, the externalized idea is a draft which facilitates the further, collaborative work." (Ibid). Viewed from a problem finding and problem solving perspective, the draft can be said to be this externalized problem statement that not only makes the problems to be worked on clear to the director and scriptwriter, but also opens the process to other people in the next stages of developing the script.

In the case of Lille soldat the move to the first draft was based more on economic and logistical considerations than an artistic urge to converge and formulate a problem statement. In many ways the first draft mirrors the final film, having found the environment for the film, the two main protagonists, and a conflict between the two focusing on the complicated relationship between father and daughter. However, major changes to the script were made based on the following process of what Isaksen and Treffinger's model identifies as the stage of generating ideas.

\section{Generating ideas (idea-finding)}

Isaksen and Treffinger's approach to CPS highlights the ability to use the process flexibly, which is important in understanding the nature of a collaborative scriptwriting process. During the writing, new problems are continuously formulated, requiring new understanding, new generating of ideas, and new plans for action. The process is not compartmentalized as indicated by the ongoing process of research that took place during the writing of Lille soldat.

At a late stage in the process it was decided to change the nationality of the escort girl in the story from being Latvian to being Nigerian and this of course led to a whole new process of research. When an expert reader from the environment pointed out that the locations for the film were depicted much too luxuriously, this led to new research about other, shabbier settings. When it became clear that actor Jesper Christensen was not able to play the part of the father 
because of conflicting schedules with the shoot of the James Bond-film Quantum of Solace, the script was changed based on input from - and the personality of - the new actor Finn Nielsen. Input from research was continually incorporated into the script when new ideas and new challenges demanded new knowledge.

However, the overall process of scriptwriting did move into a different, second stage after the formulation of the first draft. The film consultant responded positively to the project proposal, giving financial support for the writing and developing of the script. This issue of acceptance can be seen as crucial for the shift from one stage to another, since it can seem futile to spend time and money on developing an idea which is not of interest to the people who have the financial power to secure its production in the last stage of the process. The first draft is thus used to test the general interest in the idea and then consider the comments on problems to work on in the following idea generating stage which is described as the stage in which you brainstorm as many ideas or alternatives as possible for dealing with your problem statement (Isaksen \& Treffinger, 1985, p. 93). The point is to generate an idea pool from which one can draw when putting together a variety of solutions to the problem.

The money for developing the script was used to open up the writing process to not only the main actors but also to members of the A-team. This process of generating ideas in collaboration with other participants in the project is important to Olesen and Aakeson, who have developed their previous three feature films with inspiration from the so-called Mike Leigh-method, using improvisations with actors to generate material for writing the script. ${ }^{9}$ Olesen has described her role in this process as an "editor rather than the carrier of the vision", who chooses from the vast material generated by the actors (Christensen, 2002). In the case of Minor Mishaps there were 80 hours of material from which to build a story.

From early on in the process it was Olesen and Aakeson's intention to involve the actors as soon as possible. However, since the research process was complicated because it was hard to get access to people in the secretive environments, they postponed it, so the actors were not involved until September, when there was a reading of the 8th draft of the script with Jesper Christensen and Trine Dyrholm.

\section{Methods for collaborative idea generation: reading, improvisations and A-team meeting}

For Olesen, a reading is an investigation of a text where one discovers the strengths and weaknesses in the writing. A reading is not about entertaining or performing for each other. It is about hearing the text come alive and having a discussion about the problems in the text and how to solve them. The reading of Lille soldat generated many different ideas and discussions. There were two issues that ended up having a major impact on the script. Firstly Christensen and Dyrholm suggested a new, controversial ending, and secondly they also recommended that their characters find it much more difficult to communicate. Aakeson has a talent for writing good dialogue, but according to the actors the two main characters did not express themselves in a catchy way. Rather, they communicate by not saying things and having a more physical sort of father-son relationship, even though they are father and daughter. 
Following the reading, there were another three meetings to go through a rewrite of the script and two days of improvisations with the actors. These talks and improvisations also generated influential material for the script, in both the overall storyline, situations in certain scenes and specific dialogue. The A-team was also invited to come to a meeting in October to give their input and ideas about the photography, the sound, the music, the editing, and the production design, giving them the opportunity to influence the script, rather than just illustrate or embellish a finished script later in the process. Among other things, this sparked discussions about the characters' backgrounds (for instance when the composer asked what music the father sings at karaoke, or what music the female soldier listens to), as well as discussions about the rhythm and feel of the story with the many driving scenes.

This process of collaborative generation of ideas is central to the process of both Olesen and Aakeson, since it provides input from people with different angles on the script than their own. The actors focus on their characters, the photographer on which images he imagines when reading the story, etc. This enables the script to be read from many different points of views. According to Aakeson this generates invaluable ideas as 'gifts' that he and Olesen would never have been able to come up with themselves. Their extensive knowledge from their particular field is put to use for the writing process, creating more possibilities and nuances to choose from (Aakeson 2008).

This diverging collective idea generation from reading, meetings and improvisations is thus of great importance to the process of rewriting and exploring different versions of the idea in several drafts before moving on to the stage of planning for action and finding the best solutions for the script. This move was very much motivated by the film consultant, who in October allocated more money for a final write up stating that she would really like this film to be made based on the draft she had read (official draft \#2, internal draft \#10). A deadline for a suggestion for a final draft was set for the beginning of November.

\section{Planning for action (solution-finding, acceptance-finding)}

During scriptwriting a number of choices have to be made when analyzing all the material gathered and all the ideas generated to find the best way to write the plan for action, the final draft of the screenplay. In the case of Lille soldat, this final solution-finding process was very much a dialogue between Olesen and Aakeson, with Aakeson providing different versions of the script, which they could then discuss. Based on the discussions Aakeson would then do another rewrite. They are in the scriptwriting process together, but as Aakeson underlines, Olesen never writes anything: "We start with nothing, we agree on the material, and we mould the story together. She doesn't touch the keyboard. It is the story that we make, and I am then the scriptwriter." (Aakeson, 2008) The roles of the director and scriptwriter become clearer in the solution finding process. There was not much disagreement between director and scriptwriter in the process, but in the few cases where they did not agree it was natural for Aakeson that Olesen - as the director making the film - had the final say.

However, in the case of filmmaking this process of making changes and finding the final solu- 
tion for the script is not only a question of artistic choices between director and scriptwriter. While the painters in the experiment of Csikszentmihalyi and Getzels did not have people commenting on their work or financial concerns about whether it would be affordable to produce their art, the cost of making films make the comments from different gate keepers and the financial realities important parameters already during the process of writing. During all three stages in the process, the financial realities would often be discussed in the beginning of creative meetings as to assure each other that there was a possibility of this script being made into a film before going into the mode of exploring and playing.

While solution-finding according to Isaksen and Treffinger provides evaluative information on one's own personal acceptance of the solution, acceptance-finding is important since it helps make the solution acceptable to others as well (Isaksen \& Treffinger, 1985, p. 135). During the process of scriptwriting, Olesen and Aakeson at some points anticipated possible problems finding acceptance for their choices, like when they decided on the rather controversial ending from the reading and joked about who would tell the executive producer Peter Aalbæk from Zentropa, who had expressed a desire for a 'lighter film' from Olesen this time.

At the stage of planning for action, several outside comments started to have a concrete influence on the project for the first time. While the process until this point had been very much driven by intrinsic motivation, the response from outsiders commenting on the proposed script naturally led to discussions about what changes to make and for what reasons, regarding both financing and audience considerations. An example is the withdrawal from the project of TV2 late in the process because it was considered to be 'too dark'. DR took on the role of financing TV-station, but with a smaller budget proposed and with script comments leading to changes like a character being taken out of the script.

This problem of acceptance-finding is not to be under-estimated in the creative process of scriptwriting, since films are not made without finding acceptance from several people representing different financial and distributional interests. In the case of Lille soldat, both Olesen and Aakeson found that they were able to write the film they wanted to, but they were often frustrated by the response they got from the different stakeholders in the project. They thought that many people had a hard time understanding their script since the long process of developing it in collaboration creates a lot of subtext that is difficult for others to decipher.

\section{Why approach scriptwriting as a process of problem finding and problem solving?}

Using a model to analyze the different stages of scriptwriting is not to try and force a definitive model on all scriptwriting processes, but rather to use the model as a tool to ask questions like: how a collaboration progresses, where difficulties or constraints are encountered, how the roles might change along the way and of course where the actual case study challenges the model.

In the case of Lille soldat it is remarkable how the issue of acceptance finding is an influential driving force for the process. Not only at the stage of planning for action, but along the way from moving from data finding to presenting a first draft as a problem statement to the film consultant and also in moving from idea finding to solution finding in the final draft. There is a need to know 
that there is a fair chance of getting the film produced. Also the acceptance finding along the way plays an important part in the idea finding and rewriting stage, where money is needed to ask other people to contribute. As the model illustrates, outside money is often first invested after a first draft is produced and even at this point the amounts are often too small to provide an income for the director and scriptwriter as well as other collaborators. This has lately been pointed out by the Association of Danish Film Directors where many members want a greater focus - and more funding - at this front end of the process since most directors work for almost nothing until a film moves into production (Redvall, 2008a). This of course does not encourage spending a lot of time on the first stages in the process.

Logistical issues were also a driving force behind the time frame of the process, with the seasons changing and the actors having busy schedules. When asked about the stages of the process, Annette K. Olesen would have liked to have more time in the data finding process. However, she acknowledges that she has a tendency to get lost in the front end of the process because she likes the diverging part of the process and not the converging; she keeps finding new aspects that she feels she needs to know more about before being able to move on. For her, an important reason for collaborating in the process of scriptwriting is to work with a person who is strong in converging. She appreciates this ability in Aakeson to structure all the material gathered thereby forcing the process to move on by starting to suggest concrete problems to take the process in a certain direction (Olesen 2008).

For Aakeson, working with Olesen on the other hand forces him to postpone the structuring process that he sees as one of his strengths. At the same time he believes that it can turn into a weakness if it is done too early. In the collaboration with Olesen the material is kept open for a longer period of time, generating ideas and input that challenge his routines. He appreciates that the result of their collaboration is something he is convinced that he could never have produced on his own. "It didn't lose its teeth, but it became something that I could not have created myself. I mean, never have created myself." (Aakeson, 2008). Having these different approaches to diverging and converging as well as whether to stay in the mess- or data-finding rather than moving on to the problem-finding is thus an important aspect of what both director and scriptwriter appreciate in their collaboration and a major reason for collaborating in general.

Aakeson describes the process of Lille soldat as 'happy', 'appropriate' and 'satisfying', especially because of a constant feeling of moving forward: "All the time, we had the feeling of learning more. We know more than we did yesterday. The process can be hard and heavy and take a long time and things like that as long as you keep having that feeling. What is hard on you, some of the worst processes I have been in, have had the feeling of circling around. Suddenly you are back again, where you started in such a strange way - and why was it that we threw it away in the first place? (...) But this has been very much the sense of moving forward. (...) In that way it has been very satisfying." (Aakeson, 2008)

Even though the CPS-model is flexible and open to going back and forth, it is, overall, a model of moving from understanding a problem to formulating a specific plan of action. The model is helpful in showing where a process might get stuck or where difficulties are encountered. As the 
overall process of Lille soldat documents, this was a case of a fruitful flow in the process where the main gate keeper, the film consultant, kept finding improvements in the script while Olesen and Aakeson kept their interest and energy going in a process of constantly learning more about their film. This is far from always the case as documented by the many stories from 'development hell' in both US and European filmmaking.

\section{Why collaborate on scriptwriting?}

Observing the scriptwriting process of Olesen and Aakeson, there are obvious advantages in being in a process where you find yourself in good company and where there are two to stand up to the challenges of dealing with the many outside thoughts on your work. On a practical level, having both a director and a scriptwriter involved in the process allows Olesen to focus on visual input and physicality, while trusting that Aakeson takes the essential notes in the different situations during the data finding. She finds that a director and scriptwriter are often looking for very different things in the writing process. She needs visual input to make the environments and characters come alive on screen, and she finds that Aakeson learns much easier about things from reading or hearing about them. When doing research with Aakeson, he focuses on the information generated giving her the freedom to pay more attention to details, emotions and atmosphere. At the same she finds that he has a talent for 'wiping' all the information gathered when writing the script, so that all the data is not highlighted, but rather communicated in a more subtle and dramatic way to support instead of obstruct the story (Olesen, 2008)

As pointed out by many studies of group theory and teamwork (like Johnson \& Johnson 2006), this complementarity in knowledge and skills is a fundamental aspect of most collaborations. Director and scriptwriter have differentiated roles in the process, but work from a base of integrated norms and a shared vision for what to achieve. John-Steiner describes these forms of collaborations as the most widely practiced with a division of labor based on complementary expertise, disciplinary knowledge, roles and temperament.

However, while many filmmaking processes are based on the work of people with different knowledge and skills in a multiplicative process, few insist on integrating all the skills needed in the filmmaking process as a tool in the writing process. Also, while every film production puts together a team of people to collaborate, only some build on long-term collaborations. What John-Steiner terms integrative collaborations require a long period of committed activity and in some cases involves constructing a common set of beliefs to rely on if encountering difficulties.

Lille soldat is the fourth collaboration between Olesen and Aakeson. After the mixed experience of making 1:1 they started by formulating a shared agenda and vision: they wanted to learn something in the process and they wanted to make a film that might have an impact on society. JohnSteiner regards integrative partnerships as motivated by the desire to transform existing knowledge, thought styles, or artistic approaches into new visions. Thriving on a continuous dialogue about the script and deciding to run the risk of choosing 'dark' material as well as a controversial ending for the film, the collaboration between Olesen and Aakeson can, in many ways, be seen as an integrative collaboration. 
The case of Lille soldat also highlights the value of input from many other different collaborators during both the understanding of the problem and the generating of ideas. The people who research real-life environments and characters provide information and comments that are influential in challenging the original thoughts on both the theme of the story, the character building, the potential story chosen, and the nature of the environments in the story; The producer suggests having a female protagonist; The actors suggest a controversial ending; members of the A-team influence the characters, like when the composer asks what music they listen to, etc. All of this material is gathered by Olesen and Aakeson, who work in close collaboration for almost a year to create the final draft of the film.

Could this script have been written by a scriptwriter sitting at his desk, coming up with it all on his own and then handing a finished script to the director? Possibly - and that would definitely make questions about issues of authorship or intentionality easier. However, both director and scriptwriter in the case analyzed find that their collaboration has created something that they could never have created on their own, and they are both content with the process and their collaboration. As for external validation, the finished film was chosen for the main competition at the Berlin Film Festival in February 2009, which can be seen as an acknowledgment of the quality of the final film, which only had minor changes from the final draft.

\section{Conclusion}

As analyzed by a number of scholars, the creative process is often characterized by certain stages from the beginning of understanding what problem to deal with until the final solution for the problem that might - or might not - find acceptance and be considered appropriate. The process of writing a script is very much a question of learning more about which problem to solve and how to go about it. Inspired by the study of artistic problem finding by Csikszentmihalyi and Getzels, and using models from Creative Problem Solving, the intention of this article has been to shed light on the different stages of the scriptwriting process and highlight the way a discovered problem situation evolves within a close collaboration between a director and a scriptwriter. The question of when to move from a divergent to a convergent mode or when to move to the next stage in the process is central. In the case of filmmaking this is often decided not only by personal and artistic parameters by the people in the process, but to a large extent by external parameters like financing and acceptance finding as well as logistical matters, such as the availability of actors. In Lille soldat the need for preliminary acceptance finding from the film consultant and thereby financing for development of the first draft in the idea-finding stage was an important reason for externalizing the idea.

The article has addressed specific methods used for generating ideas for the script after having made a first draft as a problem statement on which to work. The reading of Lille soldat generated influential input for the script as did the meetings and improvisations with the actors. The many different members of the A-team were also asked to contribute in order to integrate their disciplinary knowledge into the written text.

This approach to writing a script shows a more dynamic way of collaborating than the tradi- 
tional compartmentalized understanding of filmmaking as a multiplicative process where actors and A-team members are more likely to be involved when a finished script is produced. This more flexible approach to the stages of idea development, scriptwriting, script development and preproduction is currently of interest to The Danish Film Institute, which has tried to rethink its funding system to encourage development money being used while the script is still open to major changes and input rather than using the money to - in a more pre-production-oriented mode - develop a script that is fundamentally considered to be finished (Redvall, 2007b).

Inspiration for future scriptwriting can be found in thinking of writing a script as a learning process with a constant shift between problem-finding and problem-solving, of diverging and converging, insisting on inviting collaborators in at the early stages of the process to help generate unexpected ideas and 'gifts'.

Hopefully, exploratory case studies of hitherto more unexplored development processes behind scriptwriting in Danish film can provide not only a greater understanding of the creative processes and collaborations at play for use in film studies, but also a reflexivity about creative work among practitioners in the industry. The model of Creative Problem Solving can be a useful tool for both analyzing the different stages of the filmmaking process and - as it is originally intended - approaching creative work with a certain mindset where finding and solving problems is a natural and continuous part of the process.

The final script for Lille soldat is the result of a close collaboration between a director and a scriptwriter who invite a number of people to contribute. There is never any question about who is the director of the film and therefore has the final say when there are minor discussions about what choices to make, but the highly collective process does challenge the traditional notion of a film being the personal statement of one auteur. Lille soldat would definitely have been a very different film - if a film at all - if Olesen had gone through the process of finding and solving the problem of what to tell and how to tell it alone or with another collaborator than Aakeson.

\section{References}

Aakeson, K.F. 2008, Research interview by Eva Novrup Redvall, April 82008.

Amabile, T. 1983, The Social Psychology of Creativity, Springer-Verlag, New York.

Amabile, T. 1996, Creativity in Context, Westview Press, Boulder, Colorado.

Bondebjerg, I. \& Hjort, M. 2001, The Danish Directors: Dialogues on a contemporary national cinema, Intellect Press, London.

Bondebjerg, I. 2005, Filmen og det moderne, Gyldendal, Copenhagen.

Bordwell, D. 1997, On the History of Film Style. Harvard University Press, Cambridge, MA.

Bordwell, D., Staiger, J. \& Thompson, K. 1985, Classical Hollywood Cinema, Columbia University Press, New York.

Carringer, R.L. 2001, 'Collaboration and Authorship, PMLA vol. 116: 2, 370-379.

Caves, R. 2000, Creative Industries, Harvard University Press, Cambridge.

Christensen, C. 2002, 'Sans for særheder', FILM 20, 3-5.

Clements, P. 1983, The improvised play: The work of Mike Leigh, Methuen, London. 
Conti, R. \& Amabile, T. 1999, Motivation/Drive, In: Runco \& Pritzke (eds). Encyclopedia of Creativity, Academic Press, San Diego.

Csikszentmihalyi, M. \& Getzels, J.W. 1971, 'Discovery'oriented behavior and originality of creative products: a study with artists', Journal of Personality and Social Psychology 19, 47-52.

Csikszentmihalyi, M. \& Getzels, J.W. 1975, 'From problem solving to problem finding', In: Taylor \& Getzels (eds). Perspectives in creativity. Aldine, Chicago.

Csikszentmihalyi, M. \& Getzels, J.W. 1976, The creative vision. A longitudinal study of problem finding in art, John Wiley and Sons, New York.

Csikszentmihalyi, M. 1988, 'Society, culture and person: A system's view of creativity', In: Sternberg (ed). The nature of creativity, Cambridge University Press.

Csikszentmihalyi, M. 1990, Flow, Harper Collins, New York.

Csikszentmihalyi, M. 1996, Creativity. Flow and the psychology of discovery and invention. Harper Collins, New York.

Csikszentmihalyi, M. 1999, 'Implications of a Systems Perspective for the Study of Creativity'. In: Sternberg (ed). Handbook of Creativity, Cambridge University Press.

Darsø, L. 2001, Innovation in the Making, Samfundslitteratur, Copenhagen.

Dewey, J. 1910, How we think, Heath, Boston.

Dillon, J.T. 1982, 'Problem-finding and solving', Journal of Creative Behavior, 16(2), 97-111.

Ecker, D.W. 1963, 'The artistic process as qualitative problem solving', The Journal of Aesthetics and Art Criticism 21, 283-290.

Fly, P. 2008, Research interview by Eva Novrup Redvall, November 112008.

Frandsen, K. 2000, 'Forskningen og afsenderleddet', Mediekultur 31, 100-106.

Frandsen, K. 2007, 'Produktionsanalyse: teoretiske og metodiske problemstillinger', In: Frandsen \& Bruun (eds). Tvproduktion: teoretiske og metodiske problemstillinger, Samfundslitteratur, Copenhagen.

Gaut, B. 1997, 'Film authorship and collaboration' In: Allen \& Smith (eds). Film Theory and Philosophy, Clarendon Press, Oxford.

Getzels, J.W. 1975, 'Problem-finding and the inventiveness of solutions', Journal of Creative Behavior, 9(1), 12-18.

Isaksen, S.G. \& Treffinger, D.J. 1985, Creative problem solving: The basic course, Bearly, Buffalo, NY.

Isaksen, S.G., Dorval, K.B., \& Treffinger, D.J. 1994, Creative approaches to problem solving, Kendall/Hunt, Dubuque, IA.

Isaksen, S.G., Dorval, K.B. \& Treffinger, D.J. 2000, Creative approaches to problem solving (2 ${ }^{\text {nd }}$ ed.), Kendall/Hunt, Dubuque, IA.

Isaksen, S.G., \& Treffinger, D.J. 2004, Celebrating 50 years of reflective practice: Versions of creative problem solving, The Journal of Creative Behavior, 38, 75-101.

Jacobsen, K. 2003, Dagbog fra Dogville, Gyldendal, Copenhagen.

Johnson, D.W. \& Johnson, F.P. 2006. Joining together: Group theory and group skills. Pearson, Boston.

John-Steiner, V. 2000, Creative collaboration, Oxford University Press, Oxford.

Miell, D. \& Littleton, K. 2004, Collaborative Creativity, Free Association Books, London.

Michelsen, L. \& Piil, M. 2006, 'Fear of Loss', FILM 48, 6-7.

Nelmes, J. 2008, Developing the Screenplay Wingwalking: An Analysis of the Writing and Rewriting Process, Journal of British Film and Television, 5:2, November 2008, 335-352.

Olesen, A. 2008. Research interview by Eva Novrup Redvall, June 202008.

Osborn, A.F. 1953/1963, Applied imagination: Principles and procedures of creative problem-solving, Schribners, New York.

Parnes, S. (ed). 1992, Source book for creative problem-solving, Creative Education Foundation Press, Hadles, MA.

Paulus, P.B. \& Nijstad, B.A. 2003, Group Creativity. Innovation Through Collaboration, Oxford University Press, Oxford. 
Philipsen, H. 2005, Dansk films nye bølge: afscet og aftryk fra Den Danske Filmskole, PhD thesis from University of Southern Denmark, Odense.

Puccio, G.J., Murdock, M.C. \& Mance, M. 2005, 'Current developments in Creative Problem Solving for Organizations: A Focus on Thinking Skills and Style', The Korean Journal of Thinking \& Problem Solving, 15(2), 43-76.

Redvall, E.N. 2007a, 'Skriverkarle og kamerakrukker. Manuskriptforfatternes indtog i auteur-kulturen efter etableringen af Filmskolens manuskriptuddannelse', Kosmorama 240, 168-184.

Redvall, E.N. 2007b, 'Transformationer, FILM 59, 8-9.

Redvall, E.N. 2008a, 'Instruktøren om udvikling', Take 46, June 2008, 9-18.

Redvall, E.N. 2008b, 'Virkeligheden som råstof og modstand for fiktionen. Om brugen af research, readings og improvisationer i udarbejdelsen af manuskriptet til Lille soldat, Kosmorama 242, 145-160.

Sawyer, K. 2008, Group genius. The creative power of collaboration. Basic Books, New York.

Schepelern, P. 2001, 100 års dansk film, Rosinante, Copenhagen.

Schepelern, P. 2005, 'The making of an auteur. Notes on the auteur theory and Lars von Trier', In: Grodal, Larsen \& Laursen (eds), Visual authorship. Creativity and intentionality in media, Museum Tusculanum, Copenhagen.

Schmidt, K. 1995, Film. Historie, kunst, industri. Gyldendal, Copenhagen.

Sellors, P.C. 2007, 'Collective authorship in film', Journal of Aesthetics and Art Criticism, vol 65: 3, 263-271.

Sternberg, R.J. \& Lubart, T.I. 1999, 'The concept of creativity: Prospects and paradigms', In: Sternberg (ed). Handbook of Creativity, Cambridge University Press.

Strandvad, S.M. 2008, Inspirations for a new sociology of art, PhD thesis, Dept. of Organizational Studies, Copenhagen Business School.

Tardini, I. 2008, Research interview by Eva Novrup Redvall, August 202008.

Taylor, T. 1999, The Big Deal. Hollywood's Million-Dollar Spec Script Market, William Morrow, New York.

Tybjerg, C. 2005, 'The makers of movies. Authors, subjects, personalities, agents?', In: Grodal, Larsen \& Laursen (eds). Visual authorship. Creativity and intentionality in media. Museum Tusculanum, Copenhagen.

von Trier, L.1998, Idioterne. Manuskript. Dagbog, Gyldendal, Copenhagen.

Wallas, G. 1926, The art of thought, Harcourt, Brace and Company, New York.

Wasko, J. 2003, How Hollywood Works, Sage, London.

Weisberg, R.W. 2006, Creativity. Understanding Innovation in Problem Solving, Science, Invention, and the Arts. John Wiley \& Sons, Hoboken, NJ.

Yin, R.K. 2003, Case study research, Sage, Thousand Oaks, CA.

\section{Notes}

1. Csikszentmihalyi and Getzels had previously emphasized the importance of problem finding in a number of articles (e.g. Getzels, 1975; Csikszentmihalyi \& Getzels, 1971, 1975) and continued writing about the creative process with especially Csikszentmihalyi's idea of a systems approach to creativity studies $(1988,1996,1999)$ and his concept of flow $(1990,1996)$ becoming widely known. As noted by Dillon (1982) and in Parnes' fifty year digest of Creative Problem Solving (CPS) (1992) their work has been influential in insisting on having a sustained discussion about the often less visible process of problem-definition and problem-finding in relation to CPS, which will be discussed later in this article.

2. Csikszentmihalyi and Getzels discuss the five stages of the problem-solving process that were introduced by American philosopher and psychologist John Dewey in How We Think (1910), and how Ecker (1963) later reworked Dewey's ideas for analyzing the artistic process. A number of scholars studying creativity still find inspiration in Dewey's description of different stages of reflection (e.g. Darsø, 2001; 'The Thinking Skills Model' 
of Puccio et al., 2005). Dewey's claim that a problem well-defined is half-solved is a popular quote in relation to creative problem finding and problem solving (Parnes, 1992).

3. Osborn's original model for CPS consisted of the seven steps of orientation, preparation, analysis, hypothesis, incubation, synthesis and verification (Osborn, 1953). He later modified the model into three steps of fact-finding, idea-finding and solution-finding (Osborn, 1963).

4. The research was based on a triangulation design of participant observation (of several meetings, reading, and improvisations), qualitative interviews during the process as well as document analysis of pitches and drafts of the script in combination with correspondence and notes about the script. Complementary interviews were later conducted with Olesen, Aakeson, producer lb Tardini and others. The direct and indirect quotes in the analysis are from the five hours of taped interviews.

5. Furthermore, I wanted to focus on a film aiming for funding from the artistic consultancy scheme of The Danish Film Institute, rather than the commercially oriented 60/40-scheme. Another basic parameter was that the film should be produced by an established production company that would make it likely that the finished script would actually go into production if the result of the process was greenlighted by the film consultant, the commissioning editor from one of the two Danish TV-channels that are nowadays essential financers of Danish film production, as well as other external funds and financers. Practical and logistical concerns were also at play, since I was to find a case to analyze during 2007/2008 and - regarding the crucial aspect of access - had to gain their trust to be allowed to study the work.

6. As pointed out by Frandsen $(2000,2007)$, production analysis is basically non-existent in Danish film studies. There are discussions of the institutional and organizational frameworks of the film industry in relation to different types of analysis of the films produced (Schmidt, 1995; Schepelern, 2001; Bondebjerg \& Hjort, 2001; Bondebjerg, 2005), and one can find diary-like documentations of the making of specific films (von Trier, 1998) or by a journalist observer of a filmmaking process (Jacobsen, 2003). However, Danish film studies do not have a tradition for detailed case studies of the work of individuals during the filmmaking process, all though more scholars have recently acknowledged the value of such studies for analyzing both the finished works as well as aspects of their authorship and intentionality (Schepelern, 2005; Tybjerg, 2005). Theories of multiple authorship (Gaut, 1997), collaboration analysis (Carringer, 2001), or collective authorship (Sellors, 2007) have challenged the traditional auteur analysis in film studies and fueled a greater interest in analyzing the complex, collective work behind the making of a film.

7. Amabile $(1983,1996)$ has studied the question of intrinsic motivation which can be defined as: "The movitation to engage in an activity solely for the enjoyment, challenge, or personal satisfaction that arises from the activity itself." (Conti \& Amabile, 1999, p. 251).

8. For more on the process of research and using reality for writing the script for Lille soldat, see Redvall 2008b.

9. The work method of Mike Leigh is described by Paul Clements in The Improvised Play (1983). It basically consists of director and actors building the characters for and developing a story through improvisations and research. 